\title{
A Study of the Factors Controlling Lactose-Fermentation in the Coliform and Paracolon Groups
}

\author{
By G. H. LOWE \\ Public Health Laboratory, Newport, Monmouthshire
}

(Received 6 February 1960)

\begin{abstract}
SUMMARY
Detailed study of a representative paracolon strain showed that the delayed fermentation of $1 \%$ lactose coincided with the development of lactose-fermenting mutants, and that the essential difference between the normal non-lactose-fermenting $\left(\mathrm{lac}^{-}\right)$organisms and the lactose-fermenting (lac $\left.{ }^{+}\right)$mutants was one of decreased permeability for lactose. Both types of organism showed the same degree of $\beta$-galactosidase activity when grown on lactose-free media; the permeability of the lac ${ }^{-}$ organisms was increased by raising the concentration of lactose in the medium. On the assumption that permeability is governed by a specific permease which is genetically distinct from $\beta$-galactosidase, a hypothetical scheme based on these two factors together with the presence or absence of hydrogenlyase suggested the existence of six phenotypes among the paracolon bacilli. In an examination of 51 naturally occurring paracolon strains four of these phenotypes were demonstrated. Since the lactose-fermenting paracolon organisms differ from coliform bacilli merely in being less permeable to $1 \%$ lactose, whereas the non-lactose-fermenting organisms differ from both the other groups in lacking $\beta$-galactosidase activity, it is suggested that the term paracolon should not be applied to this last group but should be restricted to the late-lactose-fermenters. Alternatively, these could be classed within the coliform group.
\end{abstract}

\section{INTRODUCTION}

The paracolon bacilli constitute a heterogeneous collection of organisms which are intermediate between the coliform bacilli and the salmonellas, shigellas, and other classified members of the Enterobacteriaceae. The heterogeneous nature of the paracolon group raises problems of considerable difficulty when attempts are made to classify and subdivide it. Various schemes based upon biochemical reactions and antigenic constitution have been presented but none has proved to be wholly satisfactory. The paracolon bacilli can be divided into two broad groups: the nonlactose-fermenting strains, and those strains which ferment $1 \%$ lactose slowly. These groups can be further subdivided into aerogenic and anaerogenic types. Although the non-lactose-fermenting strains form a fairly compact group which is readily distinguishable from the coliforms and the classified non-lactose-fermenting organisms, opinions differ about the classification and nomenclature of the latelactose-fermenting strains.

It is generally accepted that in the majority of instances delayed fermentation of lactose is dependent upon the development of sufficient lactose-fermenting (lac ${ }^{+}$) mutants which occur spontaneously within the bacterial population (Lewis, 1984). 
During recent years attention has been focused upon the fermentative differences between the normal non-lactose-fermenting (lac ${ }^{-}$) organisms and the lac ${ }^{+}$mutants, and it would appear that the essential distinction is one of differences in permeability to lactose, and not of lactase ( $\beta$-galactosidase) activity (Deere, 1939). Cohen \& Monod (1957) described a specific enzyme-like system, which they named 'permease', which controls penetration of galactosides to the galactosidase site; these authors claimed that permease and $\beta$-galactosidase are genetically and functionally distinct. Further studies confirming these findings were reported by Cohn \& Horibata (1959 $a$, $b, c)$. Lowe \& Evans (1957), investigating a number of strains of late-lactose-fermenting paracolon bacilli, found that rapid fermentation of lactose occurred when the concentration of lactose was increased. The results obtained suggested that, although the normal lac ${ }^{-}$organisms of the strains examined were impermeable to $1 \%$ lactose, this barrier of impermeability could to some extent be overcome by increasing the concentration of lactose (see also Cohen \& Monod, 1957). The present communication describes experiments undertaken to confirm and extend these findings and to attempt to clarify the classification of the paracolon bacilli based solely upon differences in the factors which control active fermentation of lactose.

\section{METHODS}

Organisms. The representative strain of test organism used in the preliminary experiments was originally obtained from the National Collection of Type Cultures (NCTC 8827), and will be referred to as culture E.C. 8. Fermentation of $1 \%(\mathrm{w} / \mathrm{v}$ ) lactose peptone water by this organism occurs after incubation for 3 days and coincides with the appearance of detectable lac ${ }^{+}$mutants. Colonies growing on $1 \%$ lactose peptone agar produce typical lactose-fermenting papillae after incubation for 3 days. The spontaneous mutant count is approximately one lac ${ }^{+}$mutant organism to 100,000 normal lac ${ }^{-}$organisms.

Strains of Escherichia coli and Salmonella typhimurium or Proteus rettgeri were put up in parallel with all experiments to act as controls of the media.

Media. The liquid media used were chemically defined and consisted of the following ingredients : $\mathrm{NH}_{4} \mathrm{H}_{2} \mathrm{PO}_{4}, 0 \cdot 4$ g.; $\mathrm{Na}_{2} \mathrm{HPO}_{4}, 1.2$ g.; lactose, 1 or 5 g.; glassdistilled water, $100 \mathrm{ml}$. All reagents were of analytical purity. Both media were sterilized by Seitz filtration. The solid media were prepared by mixing equal amounts of the appropriate double-strength liquid medium and sterile molten aqueous agar containing neutral red as the indicator. All media were at $\mathbf{p H ~ 7 \cdot 2 .}$

Procedure. Colonies of paracolon culture E.C. 8 grown on peptone agar were suspended in sterile distilled water and a suitable dilution made to give from one to five well separated colonies per plate on $1 \%$ and $5 \%$ lactose basal agar. Basal agar with the lactose omitted was included as a control against lactose-utilization. The inoculated plates were incubated at $37^{\circ}$ for 10 days; each day the diameters of ten selected colonies were measured and these colonies were all inspected for colour and for the appearance of lactose-fermenting papillae (see Table 1).

$A$ heavy inoculum was introduced into $100 \mathrm{ml}$. volumes of basal liquid containing, respectively, $1 \%, 5 \%$, and no lactose. Samples $(1 \mathrm{ml}$.) were withdrawn daily and tenfold dilutions made in distilled water. From each dilution 0.02 ml. was spread on $1 \%$ lactose $+0 \cdot 2 \%$ peptone agar containing neutral red, and on 
nutrient agar. The duplicate series of plates were incubated at $37^{\circ}$ and the resulting colonies counted after $24 \mathrm{hr}$. Similar total colony counts were obtained on both media. The presence of lac $^{+}$mutant cells was readily detected on the lactose + peptone agar, and a proportion of these lactose-fermenting colonies were tested daily for ability to ferment $1 \%$ lactose peptone water within $24 \mathrm{hr}$. Where the numbers of lac ${ }^{+}$mutant organisms did not exceed the expected mutant count (one lac $^{+}$organism to $10^{5}$ lac organisms) or where no lac ${ }^{+}$mutants were detected, a negative result was recorded (see Table 2).

Assay of $\beta$-D-galactosidase. The method was based upon colorimetric determination of $o$-nitrophenol liberated from the chromogenic substrate $o$-nitrophenyl- $\beta$-Dgalactopyranoside (ONPG; L. Light and Co. Ltd., Colnbrook, Bucks) when in contact with whole organisms treated with benzene (Lederberg, 1950; Rotman, 1958). The lac ${ }^{-}$normal and lac $^{+}$mutant organisms of culture E.C. 8 were each grown on $1 \%$ peptone agar and on $1 \%$ peptone agar containing, respectively, $1 \%$ lactose, $5 \%$ lactose or $1 \%$ glucose. The organisms were harvested after incubation for $24 \mathrm{hr}$. Each batch of organisms was washed twice in $0.01 \mathrm{M}$-sodium phosphate $\left(\mathrm{Na}_{2} \mathrm{HPO}_{4}\right)$ buffer $\mathrm{pH} 7.5$ and standardized by packed-cell volume to $\mathbf{0 . 2 5} \mathrm{ml}$; $35 \mathrm{ml}$. phosphate buffer and $1.75 \mathrm{ml}$. benzene were added to each batch of organisms. The mixtures were shaken vigorously for $5 \mathrm{~min}$. and then stored at $4^{\circ}$ for $24 \mathrm{hr}$. Similar preparations of Proteus rettgeri and Escherichia coli were included as negative and positive controls of $\beta$-galactosidase.

The mixtures were transferred to the $37^{\circ}$ water bath and, when temperature equilibrium had been reached, $35 \mathrm{ml}$. of $0.04 \mathrm{M}-\mathrm{ONPG}$ in sodium phosphate buffer were added to each batch of organisms. Samples $(9 \mathrm{ml}$.) were withdrawn at $5 \mathrm{~min}$. intervals and $1 \mathrm{ml}$. $\mathrm{M}$-sodium carbonate was added to stop the reaction. The samples were centrifuged at $4000 \mathrm{rev} . / \mathrm{min}$. for $20 \mathrm{~min}$. and the clear supernatant fluids used for the colorimetric determinations. The EEL portable colorimeter was used for all colorimetric determinations, with the OB 2 blue filter. Control blanks consisted of duplicate batches of benzene-treated organisms with the addition of equal volumes of sodium phosphate buffer. The ONPG control was prepared by adding $4 \mathrm{ml}$. sodium phosphate buffer and $1 \mathrm{ml}$. of $\mathrm{M}$-sodium carbonate to $5 \mathrm{ml}$. of 0.04 M-ONPG. The colorimetric readings were converted into $\mathrm{mg}$. $o$-nitrophenol liberated/100 ml., by comparing with standardized readings previously made against known concentrations of $o$-nitrophenol.

\section{RESULTS}

The results summarized in Tables 1 and 2 show the difference between the utilization of $1 \%$ and $5 \%$ lactose. In the agar series (Table 1 ) the increase in rate of colony growth on $1 \%$ lactose agar coincided with the appearance of lactose-fermenting papillae. There was usually only one papilla associated with each colony, and the papilla seemed to be entirely responsible for the increase in colony size and for the development of an acid reaction throughout the colony. Colonies growing on $\mathbf{5} \%$ lactose agar gave a progressive increase in size and acid reaction which was not dependent upon the development of papillae. Minute papillae were detected on the eighth day but these, when picked, failed to ferment $1 \%$ and $5 \%$ lactose peptone water within $24 \mathrm{hr}$. Colonies of Salmonella typhimurium developed on all these types of agar in a manner similar to that of culture E.C. 8 on the non-lactose basal agar. 
Table 1. Growth of culture E.C. 8 on basal agar containing $1 \%$ and $5 \%$ lactose showing colony size and development of lactose-fermenting papillae

\begin{tabular}{|c|c|c|c|c|c|c|c|c|c|c|c|c|c|c|}
\hline & \multicolumn{14}{|c|}{ Period of incubation (days) } \\
\hline & 1 & 2 & $\mathbf{3}$ & 4 & 6 & 8 & 10 & 1 & $\mathbf{2}$ & $\mathbf{3}$ & 4 & 6 & 8 & 10 \\
\hline Lactose & & Diam & eter & f col & ony ( & nm.) & & \multicolumn{7}{|c|}{$\begin{array}{l}\text { Appearance of lactose- } \\
\text { fermenting papillae }\end{array}$} \\
\hline 1 & $0 \cdot 1$ & $\mathbf{0 . 2}$ & 0.4 & $0 \cdot 6$ & $\mathbf{0 . 9}$ & $\mathbf{1 \cdot 3}$ & $1 \cdot 7$ & - & - & $(+)$ & + & + & + & + \\
\hline $\mathbf{5}$ & 0.2 & $0 \cdot 6$ & $1 \cdot 0$ & $1 \cdot 5$ & 1.9 & $2 \cdot 4$ & $\mathbf{3 \cdot 0}$ & - & - & - & - & - & $(+)$ & $(+)$ \\
\hline Nil & $0 \cdot 1$ & $\mathbf{0 \cdot 2}$ & $\mathbf{0 . 3}$ & $0 \cdot 4$ & 0.5 & $0 \cdot 6$ & 0.7 & - & - & - & - & - & - & - \\
\hline
\end{tabular}

The lactose liquid media gave results (Table 2) similar to those obtained with the lactose agar series. Although there is evidence of slight utilization of $1 \%$ lactose during the first 3 days, a considerable population increase and the development of acid coincided with the appearance of lac ${ }^{+}$mutants. In the $5 \%$ lactose medium a progressive increase in population and acid-production occurred which was not dependent upon the development of detectable lac $^{+}$mutants. The strain of Salmonella typhimurium developed in all three media in a similar manner to that of culture E.C. 8 in the lactose-free basal liquid.

Table 2. Growth of culture E.C. 8 in basal liquid medium containing $1 \%$ and $5 \%$ lactose showing acid-production and the development of lactose-fermenting mutants

\begin{tabular}{|c|c|c|c|c|c|c|c|c|c|}
\hline \multirow{3}{*}{$\begin{array}{l}\text { Period of } \\
\text { incubation } \\
\text { (days) }\end{array}$} & \multicolumn{9}{|c|}{ Basal medium } \\
\hline & \multicolumn{3}{|c|}{ Containing no lactose } & \multicolumn{3}{|c|}{ Containing $1 \%$ lactose } & \multicolumn{3}{|c|}{ Containing $5 \%$ lactose } \\
\hline & $\mathbf{N}$ & $\mathbf{F}$ & $\mathbf{p H}$ & $\mathbf{N}$ & $\mathbf{F}$ & pH & $\mathbf{N}$ & $\mathbf{F}$ & pH \\
\hline $\mathbf{0}$ & $0 \cdot 4$ & - & $7 \cdot 4$ & 0.8 & - & $7 \cdot 4$ & $\mathbf{0 \cdot 3}$ & - & $7 \cdot 4$ \\
\hline 1 & $2 \cdot 2$ & - & $7 \cdot 4$ & $\mathbf{3 . 5}$ & - & $7 \cdot 4$ & 50 & $(-)$ & $7 \cdot 2$ \\
\hline 2 & $6 \cdot 4$ & $(-)$ & $7 \cdot 4$ & 14.5 & $(-)$ & $7 \cdot 4$ & 90 & $(-)$ & $7 \cdot 0$ \\
\hline $\mathbf{3}$ & 4.8 & $(-)$ & $7 \cdot 4$ & 34 & $(-)$ & $7 \cdot 4$ & 328 & $(-)$ & $6 \cdot 6$ \\
\hline 4 & 1.8 & '- & $7 \cdot 4$ & 52 & $0 \cdot 1$ & $7 \cdot 4$ & 492 & $(-)$ & $6 \cdot 0$ \\
\hline 5 & 0.9 & - & $7 \cdot 4$ & 143 & 21 & $7 \cdot \mathbf{2}$ & 400 & $(-)$ & $5 \cdot 8$ \\
\hline 6 & 0.5 & - & $7 \cdot 4$ & 250 & 111 & $7 \cdot 0$ & 336 & $(-)$ & $5 \cdot 8$ \\
\hline 7 & $0 \cdot 3$ & - & $7 \cdot 4$ & 227 & 143 & $6 \cdot 8$ & 300 & $(-)$ & $5 \cdot 8$ \\
\hline 8 & $0 \cdot 14$ & - & $7 \cdot 4$ & 240 & 140 & 6.6 & 283 & $(-)$ & 5.8 \\
\hline 9 & 0.08 & - & $7 \cdot 4$ & $\mathbf{2 3 4}$ & 144 & $6 \cdot 4$ & 220 & $(-)$ & $5 \cdot 8$ \\
\hline 10 & 0.04 & - & $7 \cdot 4$ & 192 & 180 & 6.0 & 150 & $(-)$ & 5.8 \\
\hline
\end{tabular}

$\mathbf{N}=$ number of viable non-lactose-fermenting organisms (millions/ml.); $\mathbf{F}=$ number of viable lactose-fermenting mutants (millions/ml.); $-=$ no lac ${ }^{+}$mutants detected; $(-)=$lac $^{+}$mutants detected but not exceeding the expected mutant count (one lac ${ }^{+}$organism to $10^{5}$ lac $^{-}$organisms).

The $\beta$-galactosidase activity of the lac ${ }^{-}$normal and $\operatorname{lac}^{+}$mutants of culture E.C. 8 is shown in Fig. 1. The galactosidase activity of both types of organism when grown on peptone agar was similar, and depression of enzyme activity was apparent with the glucose-grown organisms. The normal lac ${ }^{-}$organisms when grown on $1 \%$ lactose showed increased activity, and this was further increased when they were grown on $5 \%$ lactose. The galactosidase activity obtained with the lac ${ }^{+}$mutants grown on $1 \%$ or $5 \%$ lactose was twice that of the lac ${ }^{-}$organisms grown on $5 \%$ 
lactose. The results suggest that the $\beta$-galactosidase activity of the lac ${ }^{-}$organisms and lac $^{+}$mutants when grown on peptone agar and glucose agar was similar and of a constitutive nature. It would also appear that the normal lac ${ }^{-}$organisms are not wholly impermeable to $1 \%$ lactose, and that substrate penetration is increased by higher concentrations of lactose. The essential fermentative difference, therefore, between the normal lac ${ }^{-}$organisms and the lac ${ }^{+}$mutants of culture E.C. 8 is one of variable permeability to lactose and not of $\beta$-galactosidase content. These results are in agreement with the original findings of Deere (1939).

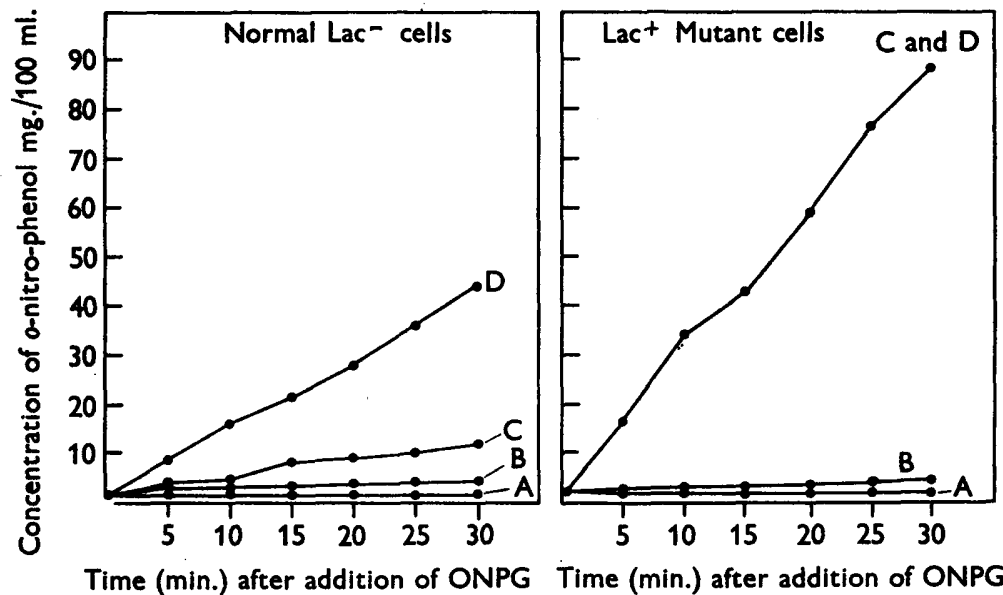

Fig. 1. $\beta$-D-Galactosidase activity of the normal lac ${ }^{-}$organisms and lac ${ }^{+}$mutants of culture E.C. 8. $\mathbf{A}=$ organisms grown on $1 \%$ glucose peptone agar; $\mathbf{B}=$ organisms grown on peptone agar; $\mathbf{C}=$ organisms grown on $1 \%$ lactose peptone agar; $\mathbf{D}=$ organisms grown on $5 \%$ lactose peptone agar.

The formulation of phenotypes to be expected among the paracolon bacilli

If rapid permeation of lactose to the $\beta$-galactosidase site is controlled by a specific genetically distinct permease (Cohen \& Monod, 1957) one would expect a definite number of phenotypes among the naturally occurring paracolon bacilli. These phenotypes should be readily identified by their: (1) fermentative reactions towards 1 and $5 \%$ lactose, (2) $\beta$-galactosidase activity, (3) production of lac ${ }^{+}$mutants possessing functional permease and galactosidase systems. The determination of hydrogenlyase activity in glucose peptone water would also distinguish between the aerogenic and anaerogenic types. Table 3 shows a tentative scheme for grouping these expected types. Normal and anaerogenic types of Escherichia coli have been selected to represent the naturally occurring strains of the phenotypes hydrogenlyase $+\left(\mathbf{H}^{+}\right), \beta$-galactosidase $+\left(\mathbf{G}^{+}\right)$, permease $+\left(\mathbf{P}^{+}\right)$, and $\mathbf{H}^{-} \mathbf{G}^{+} \mathbf{P}^{+}$, respectively. Cohn \& Horibata $(1959 a, b, c)$ used the letters $Y$ and $Z$ to denote the galactosidase permease and $\beta$-galactosidase systems. To test the validity of such a scheme, a number of naturally occurring paracolon bacilli were examined. The majority of the strains were isolated from human faeces (normal and diarrhoeal specimens) and from water samples examined at this laboratory. All strains were biochemically or serologically distinct from the principal classified members of the Enterobacteriaceae. 
Strains of Escherichia coli, E. coli anaerogenic type, Shigella sonnei, S. dispar and $S$. alkalescens were also included in this series. Approximately $10^{8}$ organisms of each culture grown on peptone agar were introduced into $5 \mathrm{ml}$. of standard $1 \%$ lactose and $1 \%$ glucose peptone water containing Andrade's indicator and a Durham tube for the detection of gas. A similar inoculum was added to $5 \mathrm{ml}$. of $5 \%$ lactose $0.1 \%$ peptone water which was prepared according to the formula of Lowe \& Evans (1957). The presence of lac ${ }^{+}$mutants was confirmed by plating from the fermented $1 \%$ lactose peptone water tubes on to $1 \%$ lactose $\mathbf{0 . 2} \%$ peptone agar containing

Table 3. A possible scheme for paracolon phenotypes

\begin{tabular}{|c|c|c|c|c|c|c|}
\hline \multirow[b]{2}{*}{$\begin{array}{l}1 \% \text { glucose } \\
\text { peptone } \\
\text { water } \\
\text { fermenta- } \\
\text { tion }\end{array}$} & \multicolumn{2}{|c|}{$\begin{array}{l}1 \% \text { lactose } \\
\text { peptone water }\end{array}$} & \multirow{2}{*}{$\begin{array}{c}5 \% \text { lactose } \\
0.1 \% \\
\text { peptone } \\
\text { water } \\
\text { fermenta- } \\
\text { tion }\end{array}$} & \multirow{2}{*}{$\begin{array}{l}\text { Galacto- } \\
\text { sidase } \\
\text { activity }\end{array}$} & \multirow{2}{*}{\multicolumn{2}{|c|}{ Phenotype }} \\
\hline & $\begin{array}{l}\text { fermenta- } \\
\text { tion }\end{array}$ & $\begin{array}{l}\text { presence of } \\
\text { lactose- } \\
\text { fermenting } \\
\text { mutants }\end{array}$ & & & & \\
\hline AG & $\mathbf{A G}$ & & $\mathbf{A}$ & + & $\mathbf{H}^{+} \mathbf{G}^{+} \mathbf{P}^{+}$ & Escherichia coli \\
\hline AG & (AG) & + & $\mathbf{A}$ & + & $\mathbf{H}+\mathbf{G}+\mathbf{P}-$ & $\begin{array}{l}\text { Aerogenic late-lactose- } \\
\text { fermenting Paracolon }\end{array}$ \\
\hline $\mathbf{A G}$ & (AG) & + & (A) & - & $\mathbf{H}^{+} \mathbf{G}-\mathbf{P}+$ & $\begin{array}{l}\text { Aerogenic late-lactose- } \\
\text { fermenting Paracolon* }\end{array}$ \\
\hline $\mathbf{A G}$ & - & - & - & - & $\mathbf{H}^{+} \mathbf{G}^{-} \mathbf{P}-$ & $\begin{array}{l}\text { Aerogenic non-lactose- } \\
\text { fermenting Paracolon }\end{array}$ \\
\hline $\mathbf{A}$ & $\mathbf{A}$ & & $\mathbf{A}$ & + & $\mathbf{H}^{-} \mathbf{G}^{+} \mathbf{P}^{+}$ & $\begin{array}{l}\text { Anaerogenic Escherichia } \\
\text { coli }\end{array}$ \\
\hline $\mathbf{A}$ & (A) & + & $\mathbf{A}$ & + & $\mathbf{H}^{-} \mathbf{G}^{+} \mathbf{P}^{-}$ & $\begin{array}{l}\text { Anaerogenic late-lactose- } \\
\text { fermenting Paracolon }\end{array}$ \\
\hline $\mathbf{A}$ & (A) & + & (A) & - & $\mathbf{H}^{-} \mathbf{G}^{-} \mathbf{P}^{+}$ & $\begin{array}{l}\text { Anaerogenic late-lactose- } \\
\text { fermenting Paracolon }\end{array}$ \\
\hline $\mathbf{A}$ & - & - & - & - & $\mathbf{H}^{-} \mathbf{G}^{-} \mathbf{P}^{-}$ & $\begin{array}{l}\text { Anaerogenic non-lactose- } \\
\text { fermenting Paracolon }\end{array}$ \\
\hline
\end{tabular}

AG = Acid with detectable gas within $24 \mathrm{hr}$. incubation; (AG) = acid with detectable gas after more than $24 \mathrm{hr}$. incubation; $A=$ acid within $24 \mathrm{hr}$. incubation without detectable gas in 21 days; (A) = acid after more than $24 \mathrm{hr}$. incubation without detectable gas in 21 days. The presence of hydrogenlyase, $\beta$-galactosidase and permease is indicated respectively by the symbols $\mathbf{H}^{+}, \mathbf{G}^{+}$ and $\mathbf{P}+$.

* A mutant of this phenotype has been isolated from $E$. coli (Cohen \& Monod, 1957).

neutral red; lactose-fermenting colonies were confirmed by their ability to ferment $1 \%$ lactose peptone water within $24 \mathrm{hr}$. The $\beta$-galactosidase activity was determined qualitatively by adding equal volumes $(2 \mathrm{ml}$.) of $0.01 \mathrm{M}-\mathrm{ONPG}$ to dense suspensions of benzene-treated organisms which had previously been grown on peptone agar and peptone agar containing $1 \%$ and $5 \%$ lactose (as previously described). The mixtures were incubated at $37^{\circ}$ for $2 \mathrm{hr}$. before reading. The presence of galactosidase activity was indicated by the originally colourless solution becoming yellow; the change was usually progressive but the final intensity varied from strain to strain.

The results are shown in Table 4. Among the 51 paracolon strains examined only four of the six predicted phenotypes were demonstrated. With the exception of one strain, all the aerogenic strains of the $\mathbf{H}^{+} \mathbf{G}^{+} \mathbf{P}^{-}$variety behaved in the predicted 
manner. The failure of this strain to ferment $5 \%$ lactose rapidly was also apparent with the four anaerogenic strains of the phenotype $\mathrm{H}^{-} \mathrm{G}^{+} \mathrm{P}^{-}$, and it would appear that these strains are impermeable to $5 \%$ lactose. The strain of Shigella sonnei examined failed to produce detectable lac ${ }^{+}$mutants in $1 \%$ lactose peptone water even though an acid reaction was consistently obtained after incubation for 3 days; $\mathrm{lac}^{+}$mutants were, however, readily isolated from lactose-fermenting papillae which appeared on colonies growing on $1 \%$ lactose peptone agar after incubation for 3-4 days. This phenomenon was described by Cook, Knox \& Tomlinson (1951). The failure to detect strains of phenotypes $\mathrm{H}^{+} \mathrm{G}^{-} \mathbf{P}^{+}$and $\mathrm{H}^{-} \mathrm{G}^{-} \mathbf{P}^{+}$might have arisen from the comparatively small numbers of strains examined.

Table 4. The distribution of phenotypes among 51 naturally occurring paracolon strains

\begin{tabular}{|c|c|c|c|c|c|c|}
\hline & $\begin{array}{l}1 \% \text { glucose } \\
\text { peptone } \\
\text { water }\end{array}$ & $\begin{array}{l}1 \% \text { lactose } \\
\text { peptone } \\
\text { water }\end{array}$ & $\begin{array}{c}\text { Detection } \\
\text { of lac } \\
\text { mutants }\end{array}$ & $\begin{array}{l}5 \% \text { lactose } \\
\text { peptone } \\
\text { water }\end{array}$ & $\begin{array}{c}\text { Galacto- } \\
\text { sidase } \\
\text { activity }\end{array}$ & Phenotype \\
\hline \multicolumn{7}{|l|}{$\begin{array}{l}\text { Paracolon strains } \\
\text { aerogenic type }\end{array}$} \\
\hline $\begin{array}{l}39 \text { strains } \\
1 \text { strain }\end{array}$ & AG & (AG) & + & $\mathbf{A}$ & $+\}$ & $\mathbf{H}^{+} \mathbf{G}+\mathbf{P}-$ \\
\hline $\begin{array}{l}1 \text { strain } \\
\text { 3 strains }\end{array}$ & $\begin{array}{l}\text { AG } \\
\text { AG }\end{array}$ & (AG) & \pm & (A) & \pm & $\mathbf{H}+\mathbf{G}-\mathbf{P}-$ \\
\hline \multicolumn{7}{|l|}{$\begin{array}{l}\text { Paracolon strains } \\
\text { anaerogenic type }\end{array}$} \\
\hline 4 strains & $\mathbf{A}$ & (A) & + & (A) & + & $\mathbf{H}^{-} \mathbf{G}^{+} \mathbf{P}^{-}$ \\
\hline 5 strains & $\mathbf{A}$ & - & - & - & - & $\mathbf{H}-\mathbf{G}-\mathbf{P}-$ \\
\hline Escherichia coli & AG & AG & & $\mathbf{A}$ & + & $\mathbf{H}^{+} \mathbf{G}+\mathbf{P}^{+}$ \\
\hline E. coli anaerogenic type & $\mathbf{A}$ & $\mathbf{A}$ & & $\mathbf{A}$ & + & $\mathbf{H}-\mathbf{G}+\mathbf{P}^{+}$ \\
\hline Shigella sonnei & $\mathbf{A}$ & (A) & + & (A) & + & $\mathbf{H}-\mathbf{G}+\mathbf{P}-$ \\
\hline S. dispar & $\mathbf{A}$ & (A) & + & (A) & + & $\mathbf{H}^{-} \mathbf{G}+\mathbf{P}-$ \\
\hline S. alkalescens & $\mathbf{A}$ & - & - & - & - & $\mathbf{H}^{-} \mathbf{G}^{-} \mathbf{P}^{-}$ \\
\hline
\end{tabular}

AG = acid with detectable gas within $24 \mathrm{hr}$. incubation; (AG) = acid with detectable gas after more than $24 \mathrm{hr}$. incubation; $\mathrm{A}=$ acid within $24 \mathrm{hr}$. incubation without detectable gas in 21 days; (A) = acid after more than $24 \mathrm{hr}$. incubation withoutdetectable gas in 21 days; - , in the fermentation reactions (columns 2 and 4 ) $=$ no change in 21 days.

\section{DISCUSSION}

The segregation and phenotypic arrangement of the factors controlling fermentation of lactose afford a system whereby accurate relationships can be established between the coliform bacilli and the various types of so-called paracolon bacilli. However, before such a scheme can be presented some limitation must be placed on the terms 'coliform' ('coli-aerogenes'), 'paracolon' and 'lactose-fermentation'. It is suggested that the term 'coliform' be applied to those members of the group which produce acid with detectable gas within $24 \mathrm{hr}$. when a moderate inoculum $\left(10^{6}\right.$ organisms) is incubated aerobically at $37^{\circ}$ in $1 \%$ lactose $1 \%$ peptone water. The term 'anaerogenic coliform' could describe those strains which produce acid only within $24 \mathrm{hr}$. In the same way the terms 'paracolon' and 'anaerogenic paracolon' should be applied to those strains which produce acid with and without detectable gas after more than $24 \mathrm{hr}$., the fermentation reaction coinciding with the appearance of detectable lactose-fermenting mutants. These fermentation reactions should also be obtained under anaerobic conditions. 
Table 5. Suggested classification of coliform and paracolon bacilli

$1 \%$ Glucose peptone water $1 \%$ Lactose peptone water Galactosidase activity Detection of $\mathrm{Lac}^{+}$mutants Phenotype

\begin{tabular}{|c|c|}
\hline \multicolumn{2}{|c|}{ Coliform bacilli } \\
\hline $\begin{array}{l}\text { Aerogenic } \\
\text { type }\end{array}$ & $\begin{array}{c}\text { Anaerogenic } \\
\text { type }\end{array}$ \\
\hline AG & $\mathbf{A}$ \\
\hline $\mathbf{A G}$ & $\mathbf{A}$ \\
\hline+ & + \\
\hline
\end{tabular}

$\mathbf{H}^{+} \mathbf{G}^{+} \mathbf{P}^{+} \quad \mathbf{H}^{-} \mathbf{G}^{+} \mathbf{P}^{+}$

\begin{tabular}{|c|c|}
\hline Paraco & n bacilli \\
\hline $\begin{array}{l}\text { Aerogenic } \\
\text { type }\end{array}$ & $\begin{array}{l}\text { Anaerogenic } \\
\text { type }\end{array}$ \\
\hline
\end{tabular}

AG

(AG)

$+$

Non-lactose-fermenting heterogeneous strains

AG = acid with detectable gas within $24 \mathrm{hr}$. incubation; (AG) = acid with detectable gas after more than $24 \mathrm{hr}$. incubation; $A=$ acid within $24 \mathrm{hr}$. incubation without detectable gas in 21 days; $(A)=$ acid after more than $24 \mathrm{hr}$. incubation without detectable gas in 21 days.

* - In the fermentation reactions $=$ no change in 21 days.

$\dagger$ Galactosidase negative, permease positive strains may exist.

Table 5 sets out the distinguishing features of the coliform, the late-lactosefermenting and the non-lactose-fermenting paracolon bacilli. It is evident that the lactose-fermenting paracolon and the coliform strains are closely related; both possess $\beta$-galactosidase and are, therefore, indistinguishable by this criterion. The non-lactose-fermenting strains, on the other hand, lack $\beta$-galactosidase and are thereby clearly distinguishable. These resemble the coliform group no more closely than other non-lactose-fermenting groups within the Enterobacteriaceae and, it could be argued, hardly merit the term 'paracolon'. If, therefore, fermentation of lactose be accepted as a fundamental characteristic of the coliform group it should also apply to the paracolon group, and some other name should be found for the non-lactose-fermenters which have hitherto been classed within the paracolon group. Alternatively, the lactose-fermenting paracolon organisms (but not the nonlactose-fermenting strains) could be included within the coliform group.

My thanks are gratefully accorded to my director, Dr R. D. Gray, and to Drs W. H. H. Jebb and A. H. Tomlinson (Public Health Laboratory, Oxford) for much helpful advice and criticism. I am also indebted to Dr Patricia Carpenter (Dysentery Reference Laboratory, Colindale) for supplying three of the anaerogenic paracolon strains described.

\section{REFERENCES}

Cohen, G. N. \& Monod, J. (1957). Bacterial permeases. Bact. Rev. 21, 169.

Cohn, M. \& Horibata, K. (1959a). Inhibition by glucose of the induced synthesis of the $\beta$-galactosidase-enzyme system of Escherichia coli. Analysis of maintenance. J. Bact. 78, 601 .

Cohn, M. \& Horibata, K. (1959 b). Analysis of the differentiation and of the heterogeneity within a population of Escherichia coli undergoing induced $\beta$-galactosidase synthesis. J. Bact. 78, 613.

Cohn, M. \& Horibata, K. $(1959 c)$. Physiology of the inhibition by glucose of the induced synthesis of the $\beta$-galactosidase-enzyme system of Escherichia coli. J. Bact. 78, 624 .

Cook, G. T., Knox, R. \& Tombinson, A. H. (1951). Production of fermentative variants by Shigella sonnei and other 'late-fermenting' organisms. Brit. J. exp. Path. 32, 203.

Deere, C. J. (1939). On the 'activation' of the lactase of Escherichia coli mutabile. J. Bact. 37, 473. 
LEDERBRRG, J. (1950). The $\beta$-D-galactosidase of Escherichia coli, strain K-12. J. Bact. 60 , 381.

LEwIs, I. M. (1934). Bacterial variation with special reference to behaviour of some mutabile strains of colon bacteria in synthetic media. J. Bact. 28, 619 .

Lowe, G. H. \& Evans, J. H. (1957). A simple medium for the rapid detection of salmonellalike paracolon organisms. J. clin. Path. 10, 318.

Rotman, B. (1958). Regulation of enzymatic activity in the intact cell. The $\beta$-D-galactosidase of Escherichia coli. J. Bact. 76, 1. 